\title{
MOLECULAR DETECTION OF EXOTIC PHYTOPATHOGENIC BACTERIA: A CASE STUDY INVOLVING CANKER-LIKE SYMPTOMS ON CITRUS
}

\author{
R.K. TAYLOR, J.L. TYSON, R.A. FULLERTON and C.N. HALE \\ HortResearch, Private Bag 92 169, Auckland, New Zealand \\ Corresponding author: rtaylor@hortresearch.co.nz
}

\begin{abstract}
Early detection and accurate diagnoses of plant diseases are crucial if New Zealand's horticultural industries are to be protected from the destructive effects of new introductions of phytopathogenic bacteria. Citrus canker, caused by Xanthomonas axonopodis pv. citri (Xac), was eradicated from New Zealand in 1972 but continues to be a biosecurity threat to the citrus industry here. In this study we evaluated and adapted molecular diagnostic procedures for the detection of exotic phytopathogenic bacteria. These techniques were used to identify the bacteria isolated from the canker-like symptoms observed on citrus leaves in Kerikeri and allowed the elimination of Xac as the causal agent. Although the symptoms were similar to citrus canker, the causal agent was found to be Elsinoe fawcettii. The applications of the developed techniques for accurate identification of the pathogen on citrus are discussed.

Keywords: Quarantine, citrus canker, Xanthomonas axonopodis pv. citri, citrus scab, Elsinoe fawcettii.
\end{abstract}

\section{INTRODUCTION}

New Zealand has remained free of some of the more destructive phytopathogenic bacteria. However, there is always a risk of new introductions, which could have significant impacts on New Zealand's horticultural industry. Early detection and accurate identification of introduced pathogens are crucial for their prompt eradication.. Classical bacteriological methods, such as the use of selective media and biochemical assays, are time-consuming and results can be ambiguous. Molecular methods on the other hand can be particularly useful for generating accurate results rapidly enough to be of use in plant disease management and quarantine decision making. These methods are ideal for the detection of organisms of quarantine significance (quarantine organisms) as they circumvent the need for live cultures. Instead, positive controls can consist of reference DNA obtained from collaborators overseas or isolated under containment. The objectives of our research were to evaluate and standardise robust molecular diagnostic procedures for the identification of quarantine micro-organisms, such as Xanthomonas axonopodis pv. citri, that pose a biosecurity risk to New Zealand.

Xanthomonas axonopodis pv. citri (Xac) (Hasse 1915) Vauterin et al. 1995 (syn. $X$. campestris pv. citri), the causal agent of citrus canker, is a major cause of economic losses of citrus world-wide and a threat to the New Zealand citrus industry. Citrus canker was eradicated from New Zealand in 1972 (Pennycook 1989), and the Ministry of Agriculture and Forestry in 1991-92 (Dance 1993) further confirmed freedom from the disease in a nation-wide survey of citrus. Quarantine restrictions are in place to ensure the continued exclusion of this disease from New Zealand. In this study we used $\mathrm{Xac}$ as a model to develop, evaluate and adapt molecular diagnostic methods to local conditions in order to improve detection of bacterial pathogens. These methods were applied to the diagnosis of a canker-like disease observed on a commercial crop of mandarins (Citrus reticulata) cv. Richards Special. Disease symptoms on leaves were circular lesions forming pustules surrounded by a chlorotic halo. These symptoms were similar to those of citrus canker and were of concern to citrus pest scouts in Kerikeri.

In this paper we report on the identification of the causal agent responsible for the 
canker-like symptoms on citrus and discuss the diagnostic implications of identifying quarantine organisms.

\section{MATERIALS AND METHODS}

\section{Bacterial isolations}

Symptomatic leaves were surface-sterilised and small sections of tissue from the canker-like lesion margins were excised aseptically, macerated in bacteriological saline $(0.85 \% \mathrm{w} / \mathrm{v} \mathrm{NaCl})$, and left at room temperature $\left(\mathrm{ca} 20^{\circ} \mathrm{C}\right)$ for $10 \mathrm{~min}$. The resulting suspensions were streaked onto King's medium B (KB) (King et al. 1954) and incubated at $26^{\circ} \mathrm{C}$. After $48 \mathrm{~h}$, representative bacterial isolates growing from the tissue suspensions were re-streaked onto KB and incubated to obtain single colonies.

Xac reference cultures

Cultures of Xac were obtained from the International Collection of Micro-organisms from Plants (ICMP), Landcare Manaaki Whenua Research, Auckland, New Zealand. Cultures ICMP 24 and ICMP 25 isolated from Citrus sp. in New Plymouth in the 1950s were used in this study as reference controls. Due to quarantine restrictions associated with the use of live cultures of Xac, DNA was extracted under PC2 containment and used for PCR analysis only. Fungal isolations

Leaves were surface sterilised and fragments of the symptomatic areas were scraped aseptically onto a medium semi-selective for the citrus scab pathogen (Whiteside 1986). The medium consisted of potato dextrose agar amended with $400 \mathrm{ppm}$ dodine, and 100 ppm each of streptomycin sulphate and tetracycline hydroxide (DST-PDA). The plates were incubated under a $12 \mathrm{~h}$ light/dark cycle at ca $20^{\circ} \mathrm{C}$ for 5-7 days.

Detection of Xac in plant tissue

To determine if the presence of citrus tissue interferes with the efficiency of the DNA extractions or with the DNA amplification in the polymerase chain reaction (PCR), known concentrations of Xac DNA were added to healthy citrus tissue before extraction. DNA was extracted from plant material as described by Taylor et al. (2001). An enrichment step similar to the method described by Taylor et al. (2001) using Luria Broth medium was also used to recover bacteria from plant tissue.

PCR analysis

The PCR analyses of plant tissue and bacterial colonies were performed using the methods of Hartung et al. (1993) and Leite et al. (1994). The PCR-based method developed by Leite et al. (1994) can be applied for the detection and identification of phytopathogenic xanthomonads, whereas the methodology of Hartung et al. (1993) allows the specific and sensitive detection of Xac. Positive controls using genomic DNA extracted from authentic cultures of Xac and negative controls containing sterile distilled water were included in each set of reactions.

Sequencing and analysis of the $16 \mathrm{~S}$ and $23 \mathrm{~S}$ ribosomal genes

The $16 \mathrm{~S}$ and $23 \mathrm{~S}$ ribosomal genes were amplified by PCR using primers and conditions described by Hauben et al. (1997) and Anthony et al. (2000) respectively. The PCR products were further purified using the Wizard, (Promega) DNA clean up kit according to the manufacturer's protocol. Direct sequencing of the PCR products was achieved by using the same $16 \mathrm{~S}$ and $23 \mathrm{~S}$ series of primers. Both forward and reverse strands were sequenced. PCR products were sequenced by using a Taq Dye Deoxy terminator cycle kit (Applied Biosystems) and a model ABI377 automatic sequencer. Sequence data were analysed by calculating the distance matrix using the Kimura- 2 parameter method. A dendrogram estimating the relationships among strains was calculated with the UPGMA (unweighted pair group method with arithmetic averages) using the Phylip interface available on the ribosomal database project (Michigan State University 2002).

\section{RESULTS AND DISCUSSION}

Mandarin samples (cv. Richards Special) suspected of being infected with citrus canker were tested for the presence of Xac using both culturing and molecular techniques 
Biosecurity

concurrently. After $48 \mathrm{~h}$ incubation on $\mathrm{KB}$ yellow mucoid bacterial colonies were visible on plates from citrus tissue samples. These colonies were morphologically similar to Xac and other authentic cultures of Xanthomonas spp. The canker-like lesions and the Xanthomonas-like colonies isolated were diagnosed as negative for Xac by PCR analysis. The PCR tests immediately confirmed that, even though the diseased plants had symptoms similar to citrus canker and Xanthomonas-like colonies were consistently isolated, the causal agent was not the quarantine organism Xac. Furthermore, PCR analysis showed that the Xanthomonas-like organisms were unlikely to cause disease, as the genes normally responsible for pathogenicity were not detected (Fig. 1). Sequence analysis of the 16S and 23S ribosomal genes indicate that the Xanthomonas-like organisms belong to the genus Xanthomonas and more precisely cluster to the $X$. campestris subgroup. These organisms have been reported to be common epiphytes on leaf surfaces (Hirano \& Upper 1983).

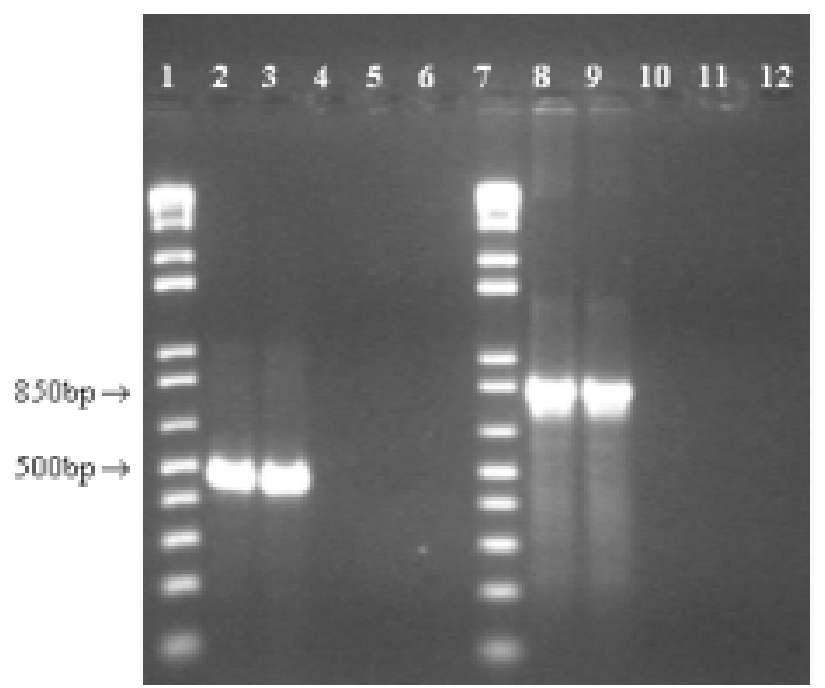

FIGURE 1: PCR analysis of Xanthomonas-like bacteria isolated from citrus. Primers for PCR detection of Xanthomonas axonopodis pv. citri (Xac) were used in Lanes 2-6, while primers used for PCR detection of phytopathogenic xanthomonads were used in Lanes 8-12. Lanes 1 \& 7: 1 kb DNA plus ladder (Invitrogen); Lanes 2 \& 8: Xac ICMP 24; Lanes 3 \& 9: Xac ICMP 25; Lanes 4-5 \& 10-11: Xanthomonas-like bacteria isolated from citrus; Lanes $6 \&$ 12: negative control.

Although the symptoms observed were similar to citrus canker, the fungal isolations revealed the causal agent to be Elsinoe fawcettii Britancourt \& Jenkins, a common fungal pathogen of Citrus spp. After several days incubation the characteristic convoluted colonies could be seen under a binocular microscope. As E. fawcettii is a primary pathogen and unable to survive saprophytically, we have confidence that it was the cause of these symptoms.

E. fawcettii is the causal agent of citrus scab and is present in most citrus-growing regions world-wide. Richards Special is considered 'apparently resistant' to citrus scab (Harty \& Sutton 1990) and the symptoms described here were unusual for the disease. More typical symptoms of citrus scab are raised, grey to light brown, corky scabs on leaves and fruit, which are often accompanied by a conspicuous distortion of the leaf laminae or fruit surface (Fullerton et al. 2001). It is thought that the unusual symptoms observed on Richards Special may be attributed to a semi-resistant host and particularly favourable environmental conditions. 


\section{Biosecurity}

Typically, citrus canker is first noticed by the characteristic symptoms that it produces on infected plants. Accurate diagnosis then relies on the isolation of the pathogen from symptomatic material and subsequent demonstration of Koch's postulates, a process which, with this disease, would take several weeks. This is an unacceptable delay where the pathogen involved is potentially a quarantine risk. In practical diagnosis, it is important that the causal agents of the plant disease be identified rapidly.

In this case study, the occurrence of saprophytes on the citrus material had similar morphology to Xac on culture media complicating accurate detection of the potential quarantine organism. This demonstrates the need to adapt and validate detection techniques for the identification of quarantine organisms to local field conditions. Techniques based on molecular methods must be validated to ensure that positive signals generated are a consequence of the presence of the target organism. The specificity of any detection technique must be evaluated when it is used to examine specified types of samples. In this case, field samples of citrus were analysed to establish the effect of resident microflora on the specificity and sensitivity of the molecular diagnostic tests. The limits of detection after PCR amplification in this study were approximately $50 \mathrm{pg}$ of target DNA in plant tissue, a level similar to that achieved in other PCR detection studies on Xac (Hartung et al. 1993). Furthermore, the use of more than one method protected against the possibility of false positive results. The molecular diagnostic protocols rapidly confirmed that the disease was not an incursion of citrus canker and prevented costly quarantine measures being taken.

\section{ACKNOWLEDGEMENTS}

The authors thank A. Harty and P. Mooney for providing the sample material. This research was funded by the Foundation for Research, Science and Technology.

\section{REFERENCES}

Anthony, R.M.; Brown, T.J.; French, G.L. 2000: Rapid diagnosis of bacteremia by universal amplification of $23 \mathrm{~S}$ ribosomal DNA followed by hybridisation to an oligonucleotide array. J. Clin. Microbiol. 38(2): 781-788.

Dance, H.M. 1993: Citrus canker surveillance; Final report. Report to the Ministry of Agriculture and Fisheries (MAF), Auckland, New Zealand.

Fullerton, R.A.; Tyson, J.L.; Sale, P.R. 2001: Citrus diseases. In: Growing citrus in New Zealand: A practical guide. HortResearch and New Zealand Citrus Growers Inc. Pp. 97-107.

Hauben, L.; Vauterin, L.; Swings, J.; Moore, E.R.B. 1997: Comparison of 16S ribosomal DNA sequences of all Xanthomonas species. Internat. J. Syst. Bacteriol. 47: 328335.

Hartung, J.S.; Daniel, J.F.; Pruvost, O.P. 1993: Detection of Xanthomonas campestris pv. citri by the polymerase chain reaction method. Appl. Environ. Microbiol. 59(40): $1143-1148$.

Harty, A.R.; Sutton, P.G. 1990: Richards Special - a promising mandarin rediscovered. Orchardist N.Z. 63 (11): 24-26.

Hirano, S.S.; Upper, C.D. 1983: Ecology and epidemiology of foliar bacterial plant pathogens. Ann. Rev. Phytopath. 21: 243-269.

King, E.O.; Ward, M.K.; Raney, D.E. 1954: Two simple media for the demonstration of pyocyanin and fluorescein. J. Lab. Clin. Med. 44: 301-307.

Leite, R.P.; Minisavage, G.V.; Bonas, U.; Stall, R.E. 1994: Detection and identification of phytopathogenic Xanthomonas strains by amplification of DNA sequences related to the hrp genes of Xanthomonas campestris pv. vesicatoria. Appl. Environ. Microbiol. 60(4): 1068-1077.

Michigan State University 2002: Ribosomal database project. http://rdp.cme.msu.edu/ html/analyses.html (16/05/02). 
Pennycook, S.R. 1989: Plant diseases recorded in New Zealand. Plant Diseases Division, DSIR, Auckland, New Zealand.

Taylor, R.K.; Guilford, P.J.; Clark, R.G.; Hale, C.N.; Forster, R.L.S. 2001: Detection of Erwinia amylovora in plant material using novel polymerase chain reaction (PCR) primers. N.Z. J. Crop Hort. Sci. 29: 35-43.

Whiteside, J.O. 1986: Semiselective media for the isolation of Elsinoe fawcettii from citrus scab pustules. Plant Disease 70: 204-206. 